\title{
Rancang Bangun Sistem Informasi Balai Pengobatan Dita Husada
}

\author{
Information System Design and Implementation for Dita Husada Hospital
}

\author{
Eka Tripustikasari ${ }^{1}$, Abdul Azis ${ }^{2}$ \\ ${ }^{1,2}$, Sistem Informasi, STMIK Amikom Purwokerto
}

\begin{tabular}{|c|c|}
\hline Informasi Makalah & INTISARI \\
\hline $\begin{array}{l}\text { Dikirim, } 13 \text { Maret } 2018 \\
\text { Diterima, } 30 \text { April } 2018\end{array}$ & $\begin{array}{l}\text { Balai Pengobatan Dita Husada adalah sebuah balai pengobatan yang } \\
\text { bergerak dalam bidang jasa kesehatan mata. BPDH mengerjakan beberapa } \\
\text { proses kerja, salah satunya di bagian administrasi. Mengikuti perkembangan } \\
\text { teknologi informasi yang berkembang BPDH akan mengupayakan } \\
\text { peningkatan proses kerja dan proses pelayanan pasien agar lebih efektif. } \\
\text { Tuiuan penelitian }\end{array}$ \\
\hline $\begin{array}{l}\text { Kata Kunci: } \\
\text { Sistem Informasi }\end{array}$ & $\begin{array}{l}\text { dapat mengolah data pasien, rekam medis dan data obat di balai pengobatan } \\
\text { dita husada; sebagai terobosan baru untuk pengembangan pelayanan pasien } \\
\text { di balai pengobatan dita husada.. }\end{array}$ \\
\hline
\end{tabular}

Balai Pengobatan.

\begin{abstract}
Dita Husada Medical Center is a medical center that specializes in eye health services. BPDH is working on several work processes, one of them. Following the development of information technology developing BPDH will seek to improve the work process and patient service process to be more effective. The purpose of this study is to process patient data that can process patient data, medical record and drug data in dita husada treatment center; as a new breakthrough for the development of patient care at dita husada medical center..
\end{abstract}

Keyword:

System Information

Clinic

\section{Korespondensi Penulis:}

Penulis Ke-1

Sistem Informasi, STMIK Amikom Purwokerto

Jl. Let. Jend. Pol. Sumarto Purwokerto

Email: ekatripustikasar@gmail.com

\section{PENDAHULUAN}

Balai Pengobatan Dita Husada adalah sebuah balai pengobatan yang bergerak dalam bidang jasa kesehatan mata. BPDH mengerjakan beberapa proses kerja, salah satunya di bagian administrasi. Mengikuti perkembangan teknologi informasi yang berkembang BPDH akan mengupayakan peningkatan proses kerja dan proses pelayanan pasien agar lebih efektif.

Saat ini proses pengolahan data pasien, rekam medis, proses administrasi dan pembuatan laporan masih menggunakan pencatatan manual menggunakan media kertas. Sehingga petugas mengalami kesulitan untuk memberikan pelayanan yang efektif, khususnya jika data yang ada sudah banyak dan pada saat pelayanan petugas membutuhkan data yang sudah lama seperti data beberapa tahun yang sebelumnya. Tempat penyimpanan data juga hanya menggunakan lemari yang memiliki kapasitas yang lebih kecil dari pada tempat penyimpanan data yang menggunakan media komputer. Data yang disimpan juga rentan mengalami kerusakan, alasanya salah satunya karena umur kertas.

Berdasarkan masalah yang dijabarkan diatas maka dibutuhkan suatu sistem informasi berbasis komputer yang dapat membantu pengolahan data pasien, rekam medis dan data transaksi sehingga pelayanan 
pasien bisa lebih efektif. Penelitian ini dilaksanakan di tempat tersebut dengan judul "RANCANG BANGUN SISTEM INFORMASI BALAI PENGOBATAN DITA HUSADA” dengan adanya sistem informasi tersebut diharapkan dapat mempermudah pekerjaan petugas dan pemeriksa dalam melayani pasien.

\section{METODOLOGI PENELITIAN}

Secara umum sistem dapat didefinisikan sebagai sekumpulan hal atau kegiatan atau elemen atau subsistem yang saling bekerjasama atau yang dihubungkan dengan cara-cara tertentu sehingga membentuk satu kesatuan untuk melaksanakan suatu fungsi guna mencapai suatu tujuan. Data dapat didefinisikan sebagai bahan keterangan tentang kejadian-kejadian nyata atau fakta-fakta yang dirumuskan dalam sekelompok lambang tertentu yang tidak acak yang menunjukan jumlah, tindakan atau hal. Data dapat berupa catatancatatan dalam kertas, buku, atau tersimpan sebagai file dalam basis data. Data akan menjadi bahan dalam suatu proses pengolahan data. Oleh karenanya, suatu data belum dapat berbicara banyak sebelum diolah lebih lanjut. Contoh data adalah catatan transaksi pembelian dan transaksi penjualan. Informasi merupakan hasil pengolahan data sehingga menjadi bentuk yang penting bagi penerimanya dan memiliki kegunaan sebagai dasar pengambilan keputusan yang dapat dirasakan akibatnya secara langsung atau secara tidak langsung pada saat mendatang. Untuk memperoleh informasi, diperlukan adanya data yang akan diolah dan unit pengolah. Contoh informasi adalah rekapitulasi transaksi pembelian pada akhir bulan, rekapitulasi transaksi penjualan pada akhir bulan, dan lain-lain [1].

Sistem informasi merupakan sistem yang berisi jaringan SPD (sistem pengolah data) yang dilengkapi dengan kanal-kanal komunikasi yang digunakan dalam sistem organisasi data. Elemen proses dari sistem informasi antara lain mengumpulkan data (data gathering), mengolah data yang tersimpan, menyebarkan informasi [2].

Basis data terdiri atas 2 kata, yaitu Basis dan Data. Basis kurang lebih dapat diartikan sebagai markas atau gudang, tempat berkumpul. Sedangkan Data gambaran fakta dunia nyata yang memeliki objek seperti manusia (pasien, dokter, siswa), barang, hewan dan peristiwa yang direkam dalam bentuk huruf, angka, simbol atau kombinasinya. Basis data sendiri dapat didefinisikan sebagai kumpulan data yang saling berhubungan yang disimpan secara bersama sedemikian rupa dan tanpa pengulangan yang tidak perlu, untuk memenuhi berbagai kebutuhan [3].

Rekam medis merupakan hasil akhtivitas pencatatan dari suatu rumah sakit atau suatu institusi pelayanan kesehatan yang berupa data. Data tersebut meliputi data sosial maupun data medis pasien rawat jalan dan rawat inap dan diproses oleh seorang tenaga rekam medis ataupun paramedis sehingga menjadi informasi yang berguna bagi rumah sakit. Adapun pengertian rekam medis adalah himpunan fakta-fakta yang berhubungan dengan riwayat hidup dan kesehatan tentang seorang pasien tersebut yang ditulis oleh professional dibidang [4].

Metode pelaksanaan yang digunakan dalam kerja praktek ini adalah metode pengembangan sistem air terjun (waterfall) dan sering disebut juga model sekuensial linier (sequential linear) atau alur hidup klasik (classic life cycle). Model air terjun menyediakan pendekatan alur hidup perangkat lunak secara sekuensial atau terurut dimulai dari analisis, desain, pengkodean, pengujian, dan tahap pemeliharaan [5].

Berikut adalah gambar dari model air terjun:

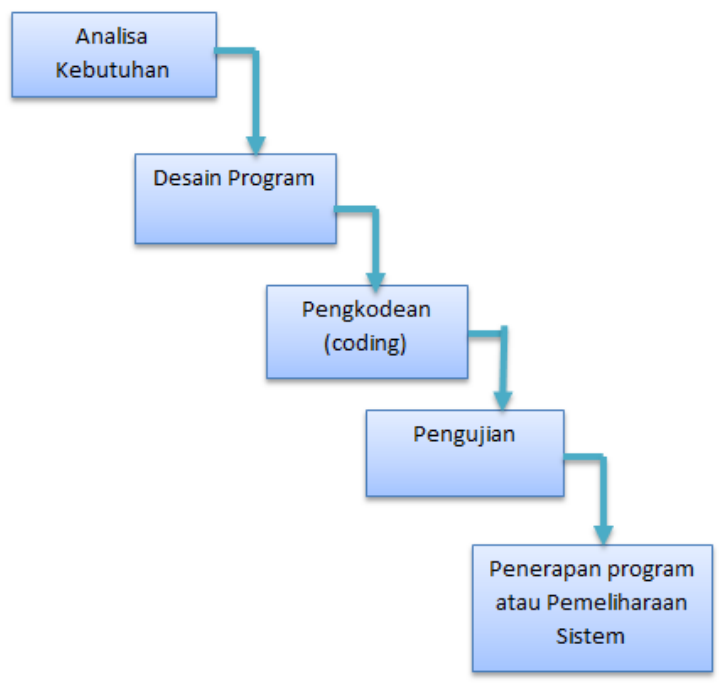

Gambar 1. Ilustrasi Model Waterfall 


\section{Analisis Kebutuhan Perangkat Lunak}

\section{Kebutuhan}

Proses analisis kebutuhan dilakukan secara intensif untuk menspesifikasikan kebutuhan perangkat lunak seperti apa yang dibutuhkan oleh user. Spesifikasi kebutuhan perangkat lunak pada tahap ini perlu untuk didokumentasikan.

Fase analisis kebutuhan merupakan fase dimana dilakukannya konsultasi dengan Kepala

Balai Pengobatan dita Husada, yang meliputi pengumpulan data untuk kebutuhan studi dan kebutuhan sistem secara teknis. Pada tahap ini terjadi proses seperti:

a. Determine requirement atau penentuan kebutuhan, hal ini dilakukan dengan cara mempelajari sistem yang masih manual menggunakan media kertas, serta menentukan kebutuhan di Balai Pengobatan Dita Husada.

b. Requirement analysis, atau analisa kebutuhan, dalam tahap ini saya menganalisa kebutuhan fungsional di Balai Pengobatan Dita Husada terhadap sistem yang akan dibuat.

2. Pengumpulan Data

a. Wawancara/Interview

Dalam kerja praktek ini dilakukan wawancara dengan Kepala dan petugas di Balai Pengobatan Dita Husada untuk mengetahui secara langsung permasalahan-permasalahan terkait dengan proses bisnis yang berjalan.

b. Observasi/Pengamatan

Observasi dilakukan dengan cara mengamati bagaimana proses yang dilakukan dalam proses transaksi dan pencatatan data pada sistem yang diterapkan sebelumnya.

Desain

Desain perangkat lunak adalah proses multi langkah yang fokus pada desain pembuatan program perangkat lunak termasuk struktur data, arsitektur perangkat lunak, representasi antar muka dan prosedur pengodean. Tahap ini mentranslasi kebutuhan perangkat lunak dari tahap analisis kubutuhan ke representasi desain agar dapat diimplementasikan mejadi program pada tahap selanjutnya. Desain perangkat lunak yang akan dihasilkan pada tahap ini juga perlu didokumentasikan.

\section{Pembuatan kode program}

Dalam tahap ini desain yang sudah dibuat ditranlasikan ke dalam program perangkat lunak. Bahasa pemograman yang digunakan adalah bahasa pemograman C\# dan database sql server 2005 dengan menggunakan report cristal report. Hasil dari tahap ini adalah program komputer sesuai dengan yang telah dibuat pada tahap desain.

\section{Pengujian}

Setelah aplikasi diimplementasikan kemudian dilakukan tahap pengujian. Pengujian fokus pada perangkat lunak secara dari segi lojik dan fungsional dan memastikan bahwa semua bagian sudah diuji. Hal ini dilakukan untuk meminimalisir kesalahan (error) dan memastikan keluarkan yang dihasilkan sesuai dengan yang dinginkan.

Pengujian software dalam penelitian ini dilaksanakan oleh pihak user atau pengguna, sedangkan untuk metode pengujian yang digunakan adalah pengujian black box. Pengertian Black Box Testing itu sendiri terfokus pada apakah unit program memenuhi kebutuhan (requirement) yang disebutkan dalam spesifikasi. Pada black box testing, cara pengujiannya hanya dilakukan dengan menjalankan atau mengeksekusi unit atau modul, kemudian diamati apakah hasil dari unit itu sesuai dengan proses bisnis yang diinginkan [6].

\section{Penerapan program atau Pemiliharaan (maintenance)}

Proses ini dilakukan setelah sistem yang dihasilkan disampaikan kepada pengguna, terutama jika sistem mengalami permasalahan yang belum ditemukan pada saat proses pengujian dan tidak menutup kemungkinan sebuah perangkat lunak mengalami perubahan ketika sudah dikirimkan ke pengguna. Permasalahan ini dapat berkaitan dengan permintaan pengguna yang membutuhkan perkembangan fungsional sistem maupun adanya penyesuaian dengan lingkungan eksternal seperti adanya perubahan sistem operasi. Tahap pemeliharaan dapat mengulangi proses pengembangan mulai dari analisis spesifikasi untuk perubahan perangkat lunak yang sudah ada, tapi tidak untuk membuat perangkat lunak baru. 


\section{HASIL DAN PEMBAHASAN}

Tujuan pengembangan sistem pada pembuatan sistem informasi balai pengobatan dita husada adalah untuk mengembangkan sistem pelayanan pasien di instansi tersebut. Serta untuk membuat dan mengimplementasikan sistem informasi yang dapat memudahkan petugas dalam melakukan pencatatan dan pengolahan data pasien, data obat dan transaksi ketika proses bisnis berjalan.

\section{Analisa Kebutuhan}

Sistem informasi balai pengobatan data husada ini memiliki beberapa kebutuhan dalam proses penerapannya:

1. Kebutuhan Hardware

Kebutuhan hardware yang diperlukan untuk implementasi sitem informasi ini adalah satu unit komputer dengan sistem operasi Windows sebagai alat untuk menjalankan aplikasi.

2. Kebutuhan Software

Kebutuhan software yang diperlukan untuk implementasi sistem informasi ini adalah SQL Server mananjemen studio 2005 yang digunakan sebagai database.

3. Kebutuhan Data

Data yang akan masuk kedalam sistem adalah berupa data pasien, obat dan data transaksi yang ada ketika proses bisnis berjalan.

4. Domain Masalah

Analisa masalah yang didapatkan pada balai pengobatan data husada, meliputi bussines requirement dan Bussines rule.

a. Bussines requirement atau penentuan kebutuhan, hal ini dilakukan dengan cara mempelajari sistem yang masih manual, serta menentukan kebutuhan di Balai Pengobatan Dita Husada. Seperti:

1) Data Pasien

2) Data Obat

3) Data Rekam Medis

4) Data Tindakan

5) Data Transaksi Pembayaran

6) Data Transaksi Pembelian Obat

7) Data Pembayaran Hutang

8) Data Pendaftaran

b. Bussines rule atau analisa kebutuhan, dalam tahap ini saya menganalisa kebutuhan fungsional di Balai Pengobatan Dita Husada terhadap sistem yang nantinya dibuat.

1) Transaksi Pembayaran

Proses ini dilakukan oleh petugas ketika pasien telah selasai melakukan pemeriksaan lalu melakukan pembayaran biaya obat dan tindakan.

2) Transaksi Pembelian Obat

Proses ini dilakukan oleh petugas ketika instansi ingin menambah stok obat sehingga melakukan pembelian obat kepada distributor. Namun pada transaksi pembelian ini, untuk biaya dibayarkan ketika 1 bulan berikutnya.

3) Transaksi Pendaftaran

Proses ini dilakukan oleh petugas ketika pasien pertama kali datang dan harus mengisi data administrasi yang nantinya dijadikan sebagai arsip balai pengobatan dita husada.

4) Transaksi Pembayaran Hutang

Proses ini dilakukan oleh petugas ketika instansi akan membayar biaya hutang ketika sebelumnya melakukan pembelian obat kepada distributor.

5) Pengolahan Rekam Medis

Proses ini dilakukan oleh pemeriksa ketika pasien telah selesai diperiksa dan didiagnosa. Data ini yang nantinya dijadikan sebagai arsip Balai Pengobatan Dita Husada dan dapat digunakan sebagai acuan untuk pemeriksaan berikutnya.

Desain

1. Desain Sistem

Sistem informasi Balai Pengobatan Dita Husada ini hanya menyediakan tiga bagian, yaitu untuk admin, pemeriksa dan petugas. Petugas hanya bisa melakukan transaksi pendaftaran, pembelian obat, pembayaran hutang, pembayaran obat dan tindakan, sedangkan untuk pencatatan yang terkait dengan stok obat dan hal-hal yang berhubungan dengan intern di Balai Pengobatan Dita Husada akan dilakukan oleh admin dan pemeriksa. 
Data-data yang telah tekumpul selama proses pengumpulan data tadi kemudian dianalisa untuk mengetahui data apa saja yang benar-benar dibutuhkan dalam proses kerja pembuatan aplikasi. Perancangan data tersebut dilakukan dengan menggunakan Unified Modeling Language (UML) untuk mengetahui apa saja yang dilakukan admin ,pemeriksa dan petugas dalam sistem.

a. Use Case

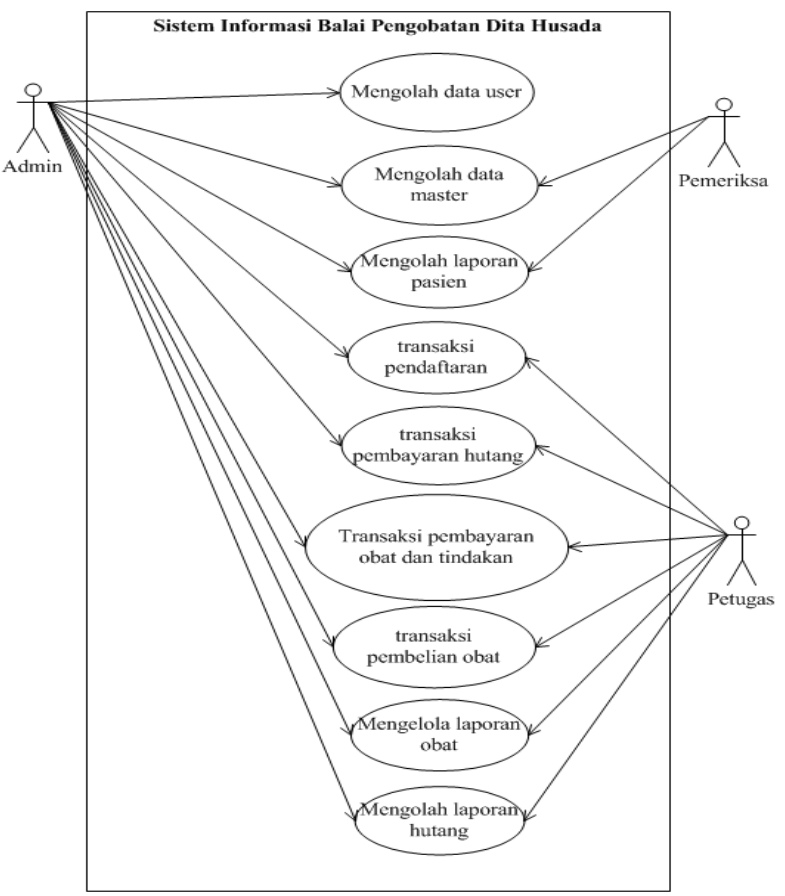

Gambar 2. Use Case Sistem informasi Balai Pengobatan Dita Husada

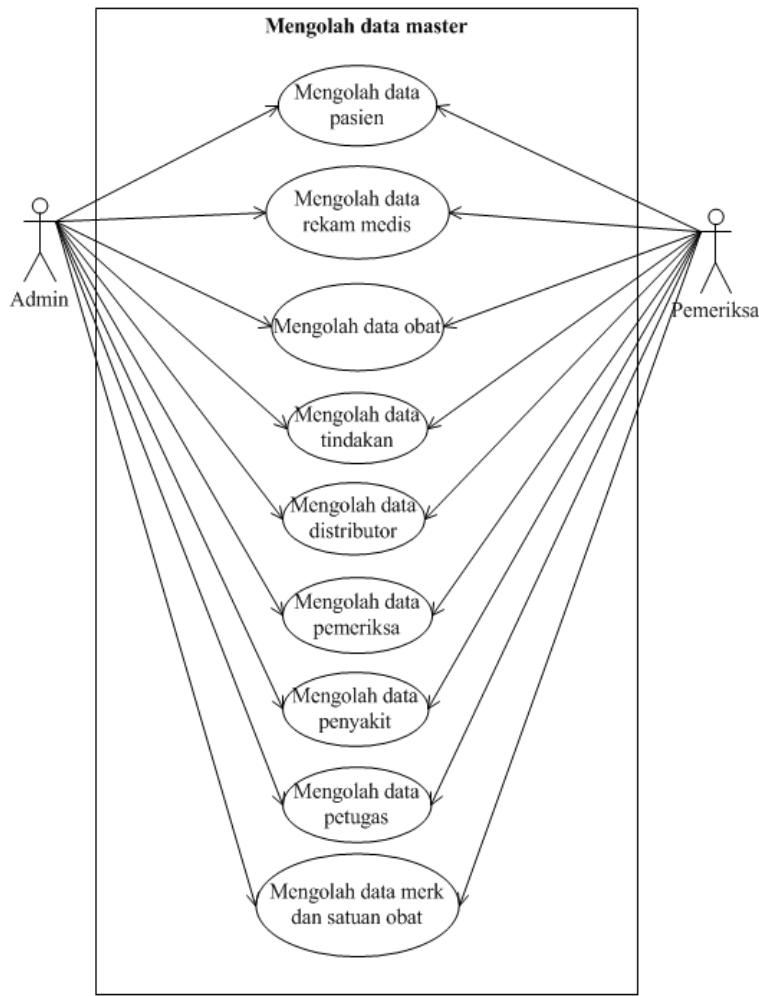

Gambar 3. Use Case Mengolah Data Master 
b. Activity Diagram

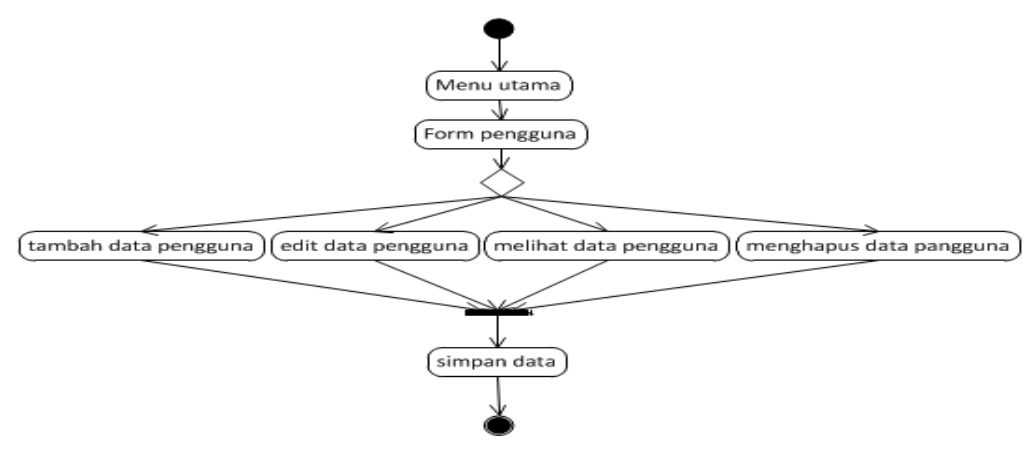

Gambar 4. Activity Diagram Mengolah Data User

Activity diagram diatas menjelaskan tentang proses pengelolaan data pengguna. Pada proses ini user terlebih dahulu masuk kemenu pengguna, kemudian masuk kedalam form pengguna. Pada saat user masuk form pengguna terdapat pilihan beberapa pilihan yaitu melihat, tambah, edit dan menghapus data pengguna. Jika user ingin melihat data pengguna yang sudah ada, user dapat melihat langsung pada gridcontrol. Jika user ingin menambahkan data pengguna, user dapat memasukan data pengguna lalu klik tambah. Jika user ingin menghapus data pengguna, user dapat memilih data pengguna yang akan dihapus lalu klik hapus. Jika user ingin mengedit data, user bisa memilih data mana yang akan diedit lalu klik simpan edit.

2. Desain Antar Muka

Rancangan antar muka merupakan rancangan yang berupa gambar mengenai menu-menu apa saja yang akan ada. Rancangan ini meliputi perancangan desain antarmuka yang telah diimplementasikan pada program Sistem Informasi Balai Pengobatan Dita Husada Adapun rancangan tersebut dapat dilihat pada gambar-gambar berikut ini:

a. Desain Menu Login

Di dalam menu login terdapat pilihan nama pengguna dan kata sandi yang akan digunakan untuk masuk ke dalam menu utama.

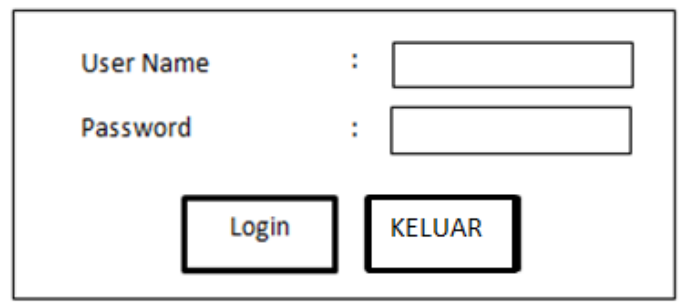

Gambar 5. Desain Menu Login

Pada gambar diatas merupakan desain untuk login, terdapat menu nama pengguna dari pengguna dan password dari pengguna. Menu login digunakan sebagai pengaman aplikasi yang digunakan untuk memberikan perlindungan terhadap aplikasi. Hanya nama pengguna yang mempunyai kata sandi yang bisa menjalankan aplikasi tersebut.

b. Desain Menu Halaman Utama

Desain menu utama merupakan tampilan utama dari aplikasi pada saat pengguna sudah melakukan login.

1) Untuk Admin 


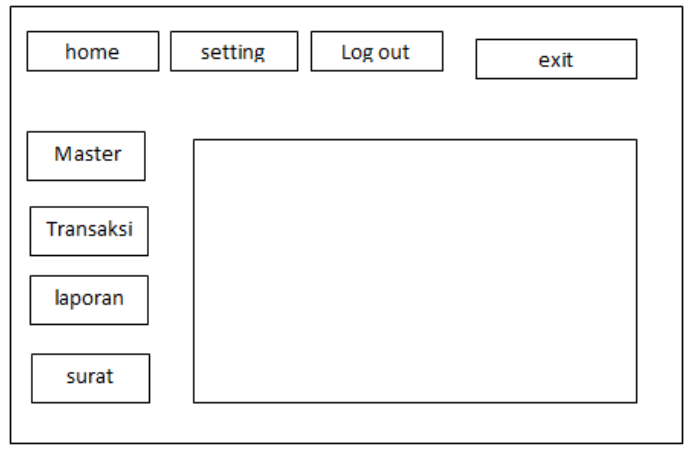

Gambar 6. Desain Menu Halaman Utama Admin

Pada Gambar diatas merupakan desain menu utama untuk admin. Pada halaman utama admin terdiri dari beberapa menu untuk home (halaman utama), pengaturan (user), logout, exit, master (pasien, obat, distributor, rekam medis, petugas, pemeriksa, merk dan satuan obat, penyakit, tindakan), transaksi (pendaftaran, pembayaran obat dan tindakan, pembayaran hutang, pembelian obat), laporan (laporan pasien, laporan obat, laporan hutang) dan surat (surat rujukan).

3. Desain Database

Dalam merancang sebuah sistem database merupakan salah satu komponen utama yang akan diolah dan dijadikan informasi. Perancangan database sendiri dalam sistem ini akan dibuat dengan menggunakan database SQL Server.

Perancangan database dilakukan dengan mengacu dari data rekam medis, pendaftaran, transaksi pembayaran obat, transaksi pembayaran tindakan, transaksi pembelian obat dan surat rujukan. Pada perancangan database ini dilakukan tiga tahapan normalisasi yaitu normalisasi tahap satu, normalisasi tahap dua dan normalisasi tahap tiga. Normalisasi merupakan teknik analisis data yang mengorganisasikan atribut-atribut data dengan cara mengelompokan sehingga terbentuk entitas yang non-redudant (perulangan), stabil, dan flexibel.

Normalisasi dilakukan sebagai uji coba pada suatu relasi secara berkelanjutan untuk menentukan apakah relasi itu sudah baik, yaitu dapat dilakukan proses insert, update, delete dan memodifikasi pada satu atau beberapa atribut tanpa mempengaruhi integritas data dalam relasi tersebut.

a. Normalisasi tahap satu

Pada tahap ini dilakukam penghilangan beberapa group elemen yang berulang agar menjadi satu harga tunggal yang berinteraksi diantara setiap baris suatu tabel, dan setiap atribut harus mempunyai nilai.

Syarat normalisasi tahap satu:

1) Tidak ada set atribut yang berulang atau bernilai ganda.

2) Telah terbentuknya primary key untuk tabel / relasi tersebut.

Berikut Hasil dari normalisasi tahap 1

a) Tabel Rekam Medis

Tabel rekam medis, dimana data medis pasien akan disimpan untuk kemudian dijadikan sebagai arsip di Balai Pengobatan Dita Husada. Data ini juga digunakan sebagai pertimbangan ketika pasien didiagnosa.

Tabel 1. Rekam Medis

\begin{tabular}{llr}
\hline \multicolumn{1}{c}{ Nama kolom } & \multicolumn{1}{c}{ Tipe data } & keterangan \\
\hline rekam_id & Varchar(255) & Primary key \\
tgl_rekam & datetime & \\
no_RM & Varchar(255) & \\
nama_pasien & Varchar(255) & \\
jenis_kelamin & Varchar(255) & \\
anamnesa & Varchar(255) & \\
riwayat_alergi_obat & Varchar(50) \\
riwayat_panyakit_terdahulu & Varchar(50) \\
riwayat_pengobatan_terdahulu & Varchar(50) \\
nama_tindakan & Varchar(255) \\
\hline
\end{tabular}




\begin{tabular}{ll}
\hline terapi & Varchar(255) \\
nama_penyakit & Varchar(255) \\
\hline
\end{tabular}

b. Normalisasi Tahap dua

Bentuk normal kedua didasari atas konsep full functional dependency ( ketergantungan functional sepenuhnya).

Syarat normalisasi tahap dua yaitu:

1) Bentuk data telah memenuhi kriteria bentuk normal kesatu.

2) Atribut merupakan bukan primary key (non key) haruslah memiliki ketergantungan functional sepenuhnya pada primary key.

Berikut hasil normalisasi tahap dua berdasarkan normalisasi tahap satu yang sudah berupa relasi diagram.

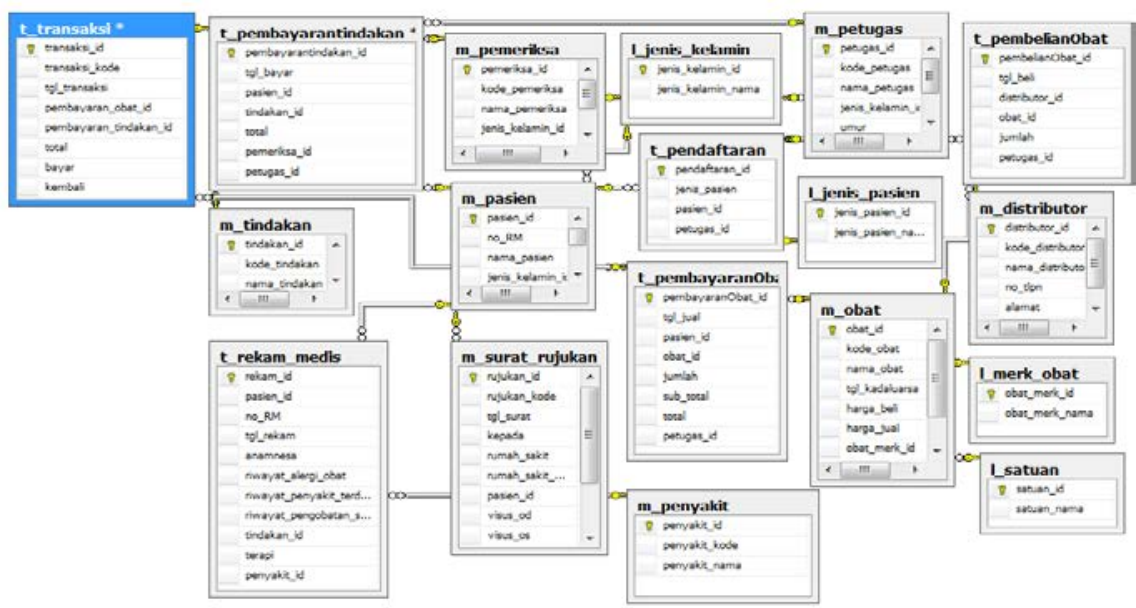

Gambar 7. Relasi Database Normalisasi 2

c. Normalisasi Tahap Tiga

Bentuk ketiga merupakan lanjutan dari bentuk normal ke dua. Pada bentuk normal ke tiga semua atribut yang memiliki ketergantungan ganda akan dipisahkan.

Berikut hasil normalisasi tahap tiga berdasarkan normalisasi tahap dua yang sudah berupa relasi diagram.

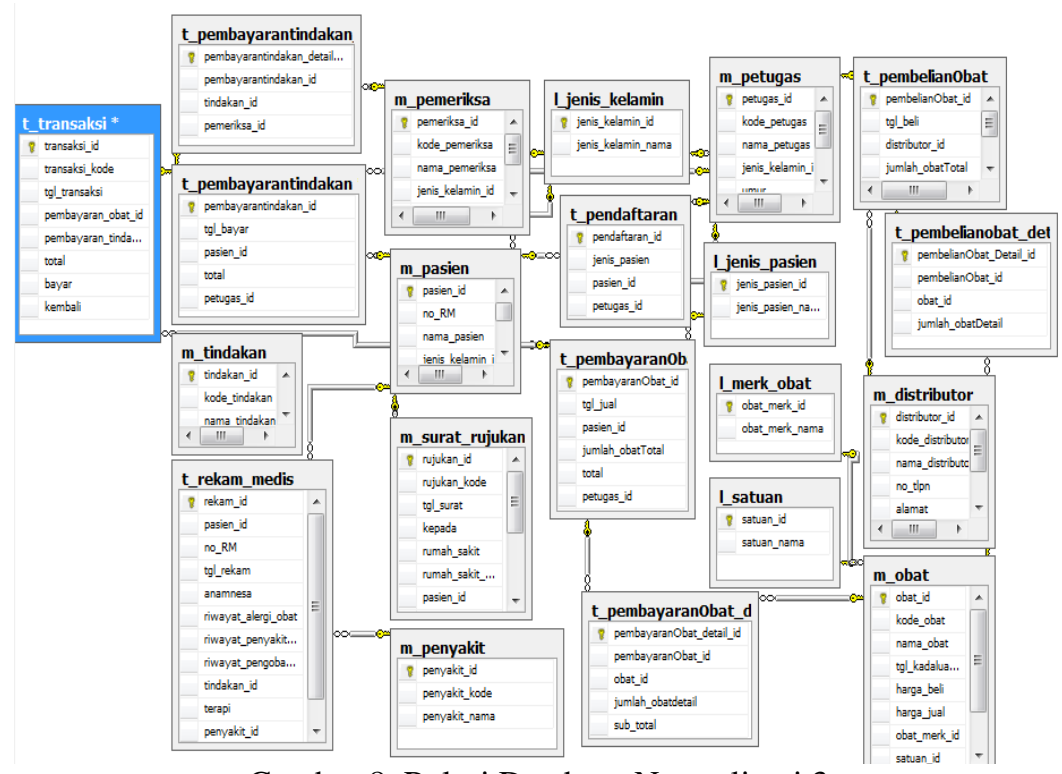

Gambar 8. Relasi Database Normalisasi 3 


\section{Pengkodingan dan Implementasi Sistem}

Dalam tahap ini desain yang sudah dibuat ditranlasikan ke dalam bentuk program perangkat lunak. Bahasa pemograman yang digunakan adalah bahasa pemograman C\# dan database sql server 2005 dengan menggunakan report cristal report. Hasil dari tahap ini adalah program komputer sesuai dengan yang telah dibuat pada tahap desain.

\section{Hasil Implementasi}

1. Form Halaman Utama

Merupakan form halaman yang akan muncul pertama kali saat aplikasi dijalankan. Pada saat pengguna belum melakukan login hanya ada menu home. Dalam menu home terdapat pilihan login, exit dan pilihan jenis tema.

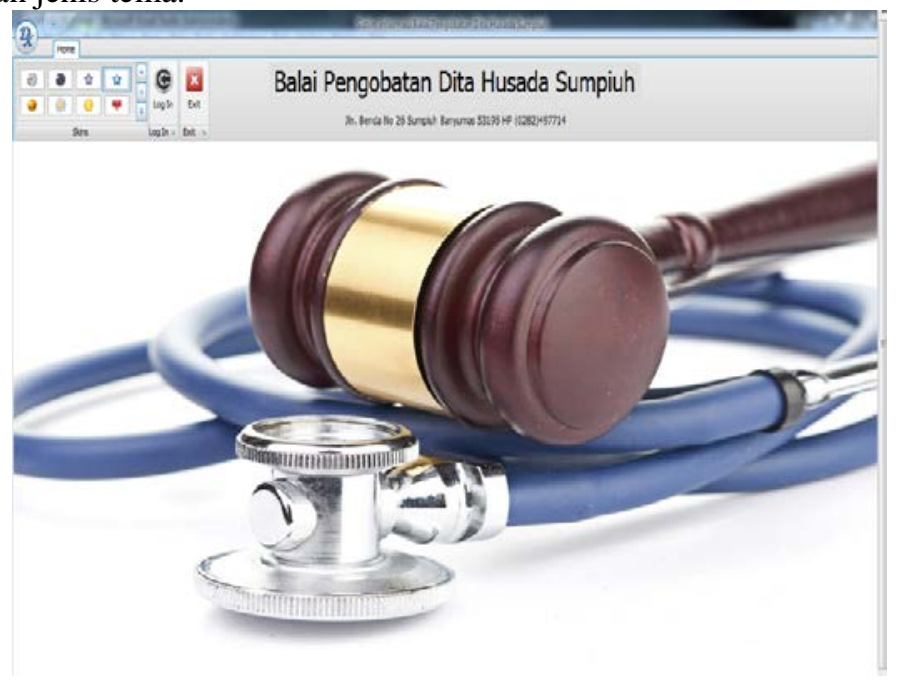

Gambar 9. Halaman Utama

2. Form Log in

Untuk dapat mengakses aplikasi, pengguna harus melakukan login terlebih dahulu. Login dilakukan dengan memilih sub menu login pada menu home. Setelah diklik maka akan muncul tampilan seperti di bawah ini.

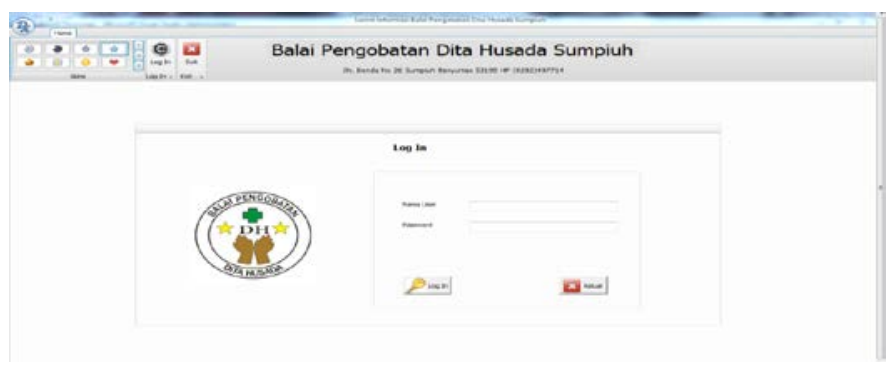

Gambar 10. Form Login

Pada gambar diatas, pengguna harus melakukan login terlebih dahulu dengan mengisikan nama pengguna dan password untuk dapat mengakses aplikasi. Jika admin melakukan kesalahan saat memasukan nama pengguna atau password, maka akan muncul peringatan seperti gambar di bawah ini. 


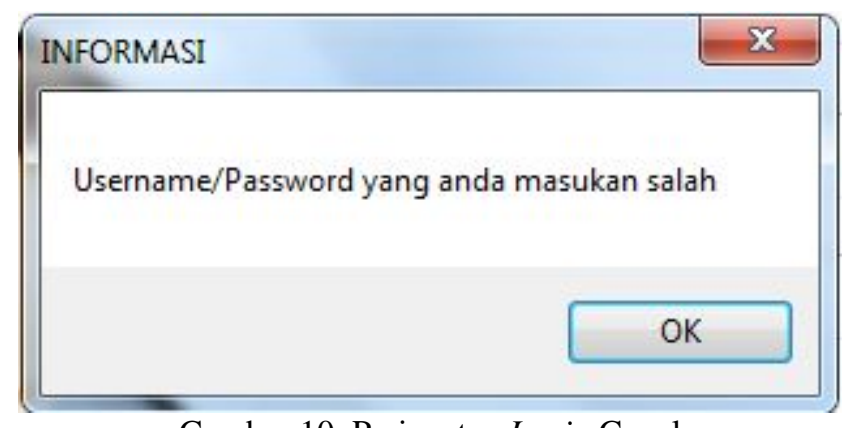

Gambar 10. Peringatan Login Gagal

\section{Hasil Pengujian Menggunakan Metode Black BoX Testing}

Setelah aplikasi diimplementasikan kemudian dilakukan tahap pengujian. Pengujian fokus pada perangkat lunak secara dari segi lojik dan fungsional dan memastikan bahwa semua bagian sudah diuji. Hal ini dilakukan untuk meminimalisir kesalahan (error) dan memastikan keluarkan yang dihasilkan sesuai dengan yang dinginkan.

Hasil penguian black-box testing pada beberapa interface dengan input atau kondisi tertentu dan tidak membahas seluruh sistem yang ada.

1. Tabel pengujian Form login

Tabel 7. Pengujian Form Login

\begin{tabular}{|c|c|c|c|}
\hline No & Pengujian & Output & Status \\
\hline 1 & $\begin{array}{l}\text { Melakukan login } \\
\text { dengan username } \\
\text { dan password } \\
\text { sebagai admin }\end{array}$ & $\begin{array}{l}\text { Tampil } \\
\text { halaman } \\
\text { utama } \\
\text { admin }\end{array}$ & Benar \\
\hline 2 & $\begin{array}{l}\text { Melakukan login } \\
\text { dengan username } \\
\text { dan password } \\
\text { sebagai pemeriksa }\end{array}$ & $\begin{array}{l}\text { Tampil } \\
\text { halaman } \\
\text { utama } \\
\text { pemeriksa }\end{array}$ & Benar \\
\hline 3 & $\begin{array}{l}\text { Melakukan login } \\
\text { dengan username } \\
\text { dan password } \\
\text { sebagai petugas }\end{array}$ & $\begin{array}{l}\text { Tampil } \\
\text { halaman } \\
\text { utama } \\
\text { petugas }\end{array}$ & Benar \\
\hline
\end{tabular}

\section{Pemeliharaan Sistem}

Fase ini merupakan fase lanjutan setelah sistem selesai diuji, pada fase ini database didalam sistem akan dilakukan back up selama 1 tahun sekali, tujuanya untuk mengurangi beban server dan untuk menjaga sewaktu-waktu terjadi kerusakan teknis pada server sehingga data bisa diselamatkan.

\section{KESIMPULAN DAN SARAN}

\section{Kesimpulan}

Berdasarkan penjelasan dari identifikasi dan rumusan masalah yang telah penulis kemukakan sebelumnya, maka dapat diambil kesimpulan bahwa dengan adanya Sistem informasi balai pengobatan dita husada diharapkan dapat membantu meningkatkan pelayanan pasien meliputi proses pengolahan data pasien, rekam medis, pendaftaran, transaksi pembayaran, pembelian obat, pembayaran hutang dan pembuatan laporan.

\section{Saran}

Setiap hasil karya tentunya kurang dari sempurna dan masih ada hal-hal yang perlu dikembangkan. Maka Saran yang dapat digunakan dalam pembuatan sistem informasi balai pengobatan dita husada ini adalah sistem informasi balai pengobatan dita husada ini sekiranya dapat dikembangkan lagi agar fitur serta fungsi yang ada nantinya lebih lengkap sehingga lebih optimal dalam pelayanan pasien, salah satunya dengan menggunakan barcode. 


\section{DAFTAR PUSTAKA}

[1] Sutanta, E. (2003). Sistem Informasi Manajemen. Yogyakarta : Graha Ilmu.

[2] Witarto. (2004). Memahami Sistem Infromasi. Bandung : Informastika Bandung.

[3] Fathansyah, I. (2007). Basis Data. Bandung : Informatika Bandung.

[4] Huffman, E.K. (1994). Health Information Management. Illyonis : Physical Record Company.

[5] Rosa, A.S \& Shalahuddin, M. (2013). Rekayasa Perangkat Lunak Terstruktur dan Berorientasi Objek. Bandung : Informatika bandung.

[6] Fatta, H.A. (2007). Analisis dan Perancangan Sistem Informasi Untuk Keunggulan Bersaing Perusahaan dan Organisasi Modern. Andi Offset. Yogyakarta. 